Article

\title{
Ustilago Rabenhorstiana-An Alternative Natural Itaconic Acid Producer
}

\author{
Susan Krull, Malin Lünsmann, Ulf Prüße and Anja Kuenz * \\ Thünen-Institute of Agricultural Technology, Bundesallee 47, 38116 Braunschweig, Germany; \\ susan.krull@thuenen.de (S.K.); malinluensmann@ymail.com (M.L.); ulf.pruesse@thuenen.de (U.P.) \\ * Correspondence: anja.kuenz@thuenen.de; Tel.: +49-531-596-4265
}

Received: 22 November 2019; Accepted: 24 December 2019; Published: 2 January 2020

\begin{abstract}
Itaconic acid is an industrial produced chemical by the sensitive filamentous fungus Aspergillus terreus and can replace petrochemical-based monomers for polymer industry. To produce itaconic acid with alternative renewable substrates, such as lignocellulosic based hydrolysates, a robust microorganism is needed due to varying compositions and impurities. Itaconic acid producing basidiomycetous yeasts of the family Ustilaginaceae provide this required characteristic and the species Ustilago rabenhorstiana was examined in this study. By an optimization of media components, process parameters, and a fed-batch mode with glucose the final titer increased from maximum $33.3 \mathrm{~g} \cdot \mathrm{L}^{-1}$ in shake flasks to $50.3 \mathrm{~g} \cdot \mathrm{L}^{-1}$ in a bioreactor. Moreover, itaconic acid was produced from different sugar monomers based on renewable feedstocks by $U$. rabenhorstiana and the robustness against weak acids as sugar degradation products was confirmed. Based on these findings, $U$. rabenhorstiana has a high potential as alternative natural itaconic acid producer besides the well-known $U$. maydis and A. terreus.
\end{abstract}

Keywords: Ustilago; itaconic acid; process improvement; lignocellulosic feedstock

\section{Introduction}

Itaconic acid is an interesting chemical for the polymer industry, which is produced in a biotechnological process based on renewable substrates [1]. Petrochemical-based substances, like methacrylic or acrylic acid, can be replaced by this single unsaturated dicarbonic acid and its derivatives. Therefore, the field of products and applications is widespread, e.g., synthetic latex, styrene-butadiene rubber, superabsorbent polymers, or unsaturated polyester resins [2-6].

Since the 1960s, the filamentous fungus Aspergillus terreus is industrially used with a titer of 85-100 g. $\mathrm{L}^{-1}$, whereas in laboratory scale, final titers of $160 \mathrm{~g} \cdot \mathrm{L}^{-1}$ itaconic acid are described [4,7-9]. A. terreus achieves a productivity up to $1.15 \mathrm{~g}(\mathrm{~L} \cdot \mathrm{h})^{-1}$ and a yield of $0.64(w / w)$, whereby the theoretical yield with glucose is $0.72(w / w)[7,8]$. Besides pure glucose, itaconic acid was successfully produced by $A$. terreus with glycerol, starch hydrolysates, molasses, and different monosaccharides, like xylose, arabinose, galactose, and rhamnose [10]. A great cultivation challenge is caused by sugar degradation products or other impurities in lignocellulosic hydrolysates, which influence the morphology and itaconic acid production of the fungus. Due to the sensitivity of the fungus, complex purification processes are used for such hydrolysates or more resistant strains are generated by mutagenesis [11-13]. Another alternative is itaconic acid producing yeasts of the species Candida, Pseudozyma, or Ustilago, which are more robust and not as sensitive to metal ions as A. terreus [14-18]. For wildtype strains of the species Ustilago, low final titers of $44.5 \mathrm{~g} \cdot \mathrm{L}^{-1}$ itaconic acid, low yields up to $0.24(w / w)$, and a low productivity of maximum $0.31 \mathrm{~g}(\mathrm{~L} \cdot \mathrm{h})^{-1}$ are disadvantageous [19]. This is due to a variety of by-products like other organic acids, glycolipids, and intracellular triacylglycerols, which are produced in parallel to itaconic acid $[16,18,20,21]$. Nevertheless, in addition to the robustness of the yeasts, 
the formation of haploid yeast-like cells is an advantage compared to the filamentous growth or formation of pellets of $A$. terreus with a decreased oxygen supply or increased viscosity [5,22].

In recent years, the research interest in itaconic acid production with the phytopathogenic basidiomycete Ustilago maydis increased. It was found, that an ammonium limitation triggers the itaconic acid overproduction in $U$. maydis $[5,19]$ and itaconic acid is synthesized in the cytosol via the intermediate cis-aconitate and trans-aconitate and can be further converted to 2-hydroxyparaconic acid [23-25]. The itaconic acid gene cluster was also characterized and relevant enzymes, transporters, and promoters were found $[23,25,26]$, whereby a summary of metabolic aspects is given by Wierckx et al. [27]. Based on these findings, metabolic engineering strategies and process optimization of $U$. maydis resulted in a reduction of by-product concentrations of malic acid and 2-hydroxyparaconic acid with a significant increased itaconic acid titer of $63.2 \mathrm{~g} \cdot \mathrm{L}^{-1}$ and a yield of $0.48(w / w)$ [23]. All in all, detailed examinations are available for itaconic acid production of $U$. maydis, but also other wildtype strains of the family Ustilaginaceae could offer advantages of less sensibility or a yeast-like morphology for using second-generation feedstocks. This family is well-known for organic acid production [16,18,28,29], but the level of knowledge about alternative itaconic acid producer, like $U$. cynodontis or $U$. rabenhorstiana, are low.

This study considers the cultivation of Ustilago rabenhorstiana for itaconic acid production and its potential as alternative natural producer. Although the used strain is known as natural itaconic acid producer $[18,30]$, the microorganism was not examined in literature more precisely. Only the growth of the organism with glycerol as substrate was described, whereby non-formation of organic acids was detected [28]. Concerning itaconic acid production based on renewable resources, usability of different sugar monomers and robustness towards influence of sugar degradation products were examined in this study. Moreover, the influences of media and fermentation parameters on the production of itaconic acid and by-products as well as the morphology of the yeast were investigated.

\section{Materials and Methods}

\subsection{Microorganism}

The basidiomycete Ustilago rabenhorstiana NBRC 8995 was purchased from the National Institute of Technology and Evaluation (Tokyo, Japan) and was stored at $-80^{\circ} \mathrm{C}$ as $50 \%(v / v)$ glycerol stock culture.

\subsection{Media Compositions}

YEPS-medium was used for the preparation of agarplates and preculture (20 g. $\mathrm{L}^{-1}$ sucrose, $10 \mathrm{~g} \cdot \mathrm{L}^{-1}$ yeast extract, $20 \mathrm{~g} \cdot \mathrm{L}^{-1}$ peptone, optional $20 \mathrm{~g} \cdot \mathrm{L}^{-1}$ agar-agar).

If not mentioned otherwise, the production media was a Tabuchi-medium [18] containing $120 \mathrm{~g} \cdot \mathrm{L}^{-1}$ glucose, $0.5 \mathrm{~g} \cdot \mathrm{L}^{-1} \mathrm{KH}_{2} \mathrm{PO}_{4}, 1.6 \mathrm{~g} \cdot \mathrm{L}^{-1} \mathrm{NH}_{4} \mathrm{Cl}, 0.2 \mathrm{~g} \cdot \mathrm{L}^{-1} \mathrm{MgSO}_{4} \cdot 7 \mathrm{H}_{2} \mathrm{O}, 10 \mathrm{mg} \cdot \mathrm{L}^{-1} \mathrm{FeSO}_{4} \cdot 7 \mathrm{H}_{2} \mathrm{O}, 1 \mathrm{~g} \cdot \mathrm{L}^{-1}$ yeast extract, and $30 \mathrm{~g} \cdot \mathrm{L}^{-1} \mathrm{CaCO}_{3}$. All components were prepared separately in stock solutions; the $\mathrm{pH}$-value was adjusted to $\mathrm{pH} 6.0$ for all solutions with $0.5 \mathrm{~m} \mathrm{H}_{2} \mathrm{SO}_{4}$ or $1 \mathrm{~m} \mathrm{NaOH}$ and autoclaved. The $\mathrm{pH}$-value of the iron-solution was not corrected, and the solution was sterile filtered. $\mathrm{CaCO}_{3}$ was weighed in the glassware and autoclaved.

All media components were p.a. quality and purchased from Merck (Darmstadt, Germany), Sigma-Aldrich (St. Louis, MO, USA) or Roth (Karlsruhe, Germany). In fed-batch cultivation the glucose concentration was monitored during the cultivation. If necessary, glucose was added in solid form without previous sterilization to prevent a glucose limitation.

\subsection{Cultivation}

Precultures were conducted in a $250 \mathrm{~mL}$ shake flask with three baffles, a filling volume of $50 \mathrm{~mL}$, and inoculated with a single colony from a YEPS-agar plate $\left(30^{\circ} \mathrm{C}, 3\right.$ days). The preculture was cultivated at $30^{\circ} \mathrm{C}$ and $120 \mathrm{rpm}$ (50 mm shaking diameter) for $24 \mathrm{~h}$ until an optical density of 10 at $605 \mathrm{~nm}$ was achieved. All experiments were inoculated with $1 \%(v / v)$ of the preculture. 
The main cultures in shake flasks were carried out at $30^{\circ} \mathrm{C}$ and $120 \mathrm{rpm}$ in $250 \mathrm{~mL}$ shake flasks with three baffles and a filling volume of $100 \mathrm{~mL}$ Tabuchi-medium.

To identify potential impurities and the utilization of monosaccharides based on lignocellulosic feedstock, test tubes with Kapsenberg caps were used and a working volume of $2 \mathrm{~mL}$ $(\varnothing 16 \mathrm{~mm} \times 100 \mathrm{~mm})$. The test tubes were incubated for 4 days at $30^{\circ} \mathrm{C}$ and $120 \mathrm{rpm}$ in an inclined test tube holder with an inclination angle of $30^{\circ}$. Shake flasks and test tubes were continuously rotated by hand while sampling avoiding inhomogeneity.

The cultivation in bioreactors were conducted in four parallel $1 \mathrm{~L}$-bioreactors, equipped with a Rushton impeller and an L-sparger (model SR0700ODLS, DASGIP GmbH, Jülich, Germany). DASGIP Control software (DASGIP GmbH, Jülich, Germany) was used for the regulation of gassing, temperature, $\mathrm{pH}$-value, and stirring rate, as well as recording the data of dissolved oxygen (DO) and $\mathrm{pH}$. The $\mathrm{pH}$ regulation to $\mathrm{pH} 6.0$ was carried out with $4 \mathrm{M} \mathrm{NaOH}$, if not otherwise mentioned. At the beginning of the cultivation, $0.5 \mathrm{~mL}$ antifoam solution (Ucolup N-115, Brenntag, Mühlheim/Ruhr, Germany) was added to the broth. The experiments were carried out at $30^{\circ} \mathrm{C}, 500 \mathrm{rpm}$, a filling volume of $500 \mathrm{~mL}$, and an aeration of $0.1 \mathrm{vvm}$, unless otherwise mentioned. All cultivations were carried out in minimum duplicates, whereby the deviation from the mean value was $<5 \%$. All results are presented as mean values without error bars on account of readability.

\subsection{Analytical Methods}

The samples were centrifuged at $21,000 \mathrm{~g}$ for $20 \mathrm{~min}$ at $20^{\circ} \mathrm{C}$ and the supernatant was used for further analysis. A Shimadzu HPLC (Shimadzu Corp., Kyoto, Japan) with a HPX-87H column (BioRad, Munich, Germany) with a refractive index detector (RI) and UV detector at $210 \mathrm{~nm}$ was used to analyze the concentrations of sugars and organic acids. The column was tempered at $40{ }^{\circ} \mathrm{C}$ and as mobile phase a $5 \mathrm{M} \mathrm{H}_{2} \mathrm{SO}_{4}$ solution at a flow rate of $0.6 \mathrm{~mL} \cdot \mathrm{min}^{-1}$ was used. The concentration of an unknown product was estimated by the peak area of the RI-signal compared to a calibration of succinic acid. For samples of bioreactor experiments, the pellet was washed twice with deionized water and dried to a constant weight at $105^{\circ} \mathrm{C}$ for at least $48 \mathrm{~h}$ to determine the cell dry weight (CDW).

The composition of fatty acids was analyzed by transesterification of the fatty acids as described by Lewis et al. [31]. The biomass of reactor cultivation was separated from the broth by centrifugation $\left(21,000 \mathrm{~g}\right.$ for $20 \mathrm{~min}$ at $\left.20^{\circ} \mathrm{C}\right)$. The supernatant was discarded, and the pellet was washed twice with $0.9 \%(v / v) \mathrm{NaCl}$-solution and suspended in $0.9 \%(v / v) \mathrm{NaCl}$-solution. The cells were disrupted by an ultrasonic-homogenisator on ice (4 cycles: $15 \mathrm{~s}$ at $65 \%$, break $30 \mathrm{~s}$; Sonopuls HD2200 with sonotrodetype UW2200, Bandelin electronic, Berlin, Germany). The suspension was stored at $-80{ }^{\circ} \mathrm{C}$ and freeze-dried (Alpha 1-2 LD, Christ, Osterode, Germany). The fatty acids were derivatized to fatty acid methyl esters (FAME) [31] and analyzed by GC-MS on a GC-17A (Shimadzu Corp., Kyoto, Japan) with a Zebron ${ }^{\text {TM }}$ ZB-WAX plus column $(60 \mathrm{~m} \times 0.25 \mathrm{~mm} \times 0.25 \mu \mathrm{m})$, using $1.4 \mathrm{~mL} \cdot \mathrm{min}^{-1}$ helium as carrier gas. The temperature gradient of $60{ }^{\circ} \mathrm{C}$ was increased to $150{ }^{\circ} \mathrm{C}$ at a rate of $30^{\circ} \mathrm{C} \cdot \mathrm{min}^{-1}$, and afterwards increased up to $240{ }^{\circ} \mathrm{C}$ at a rate of $13^{\circ} \mathrm{C} \cdot \mathrm{min}^{-1}$. The temperature of $240^{\circ} \mathrm{C}$ was kept for $30 \mathrm{~min}$ and raised to $255^{\circ} \mathrm{C}$ for $5 \mathrm{~min}$. The FAMEs were identified with the software LabSolutions (Shimadzu Corp., Kyoto, Japan) and the mass spectral data were compared with the database of the National Institute of Standards and Technology (Gaithersburg, MD, USA).

\subsection{Microscopy}

The cells were examined using a phase-contrast microscope (Axioplan, Carl Zeiss AG, Jena, Germany) with the software analysis pro (Analysis 5.1, Olympus Soft Imaging Solutions GmbH, Münster, Germany). Intracellular lipids were visualized after coloring with nil-red by fluorescence microscopy [32]. 


\section{Results}

\subsection{Standard Cultivation in Shake Flasks}

A standard cultivation of $U$. rabenhorstiana with pure glucose as substrate was performed in shake flasks (Figure 1). After one day, the itaconic acid production started, and additionally, succinic acid and malic acid were produced. Furthermore, an unknown product accumulated after $48 \mathrm{~h}$ approximately in a concentration range of $<1 \mathrm{~g} \cdot \mathrm{L}^{-1}$. Malic acid was consumed in further course of cultivation, and after four days, $\alpha$-ketoglutaric acid was formed and increased parallel with the itaconic acid concentration. Glucose was completely consumed after 9.7 days, resulting in $31.3 \mathrm{~g} \cdot \mathrm{L}^{-1}$ itaconic acid, $13.6 \mathrm{~g} \cdot \mathrm{L}^{-1}$ $\alpha$-ketoglutaric acid, $2.3 \mathrm{~g} \cdot \mathrm{L}^{-1}$ malic acid, and traces of an unknown metabolite, followed by a further production of $\alpha$-ketoglutaric acid. The overall productivity was $0.13 \mathrm{~g}(\mathrm{~L} \cdot \mathrm{h})^{-1}$ with a yield of $0.26(w / w)$ after 9.8 days. Despite the use of $\mathrm{CaCO}_{3}$ as buffer, the $\mathrm{pH}$-value constantly decreased from $\mathrm{pH} 6.8$ to 4.9 throughout the cultivation. The morphology of $U$. rabenhorstiana changed from yeast-like single cells (0-2 days; Figure 1A) via a development of pseudomycel (2-7 days, Figure 1B) to filamentous growth like long branched mycel (7-11 days, Figure 1C). Moreover, intracellular lipids deposits were visible under the microscope, which became smaller in size after the glucose limitation at day 9.7.
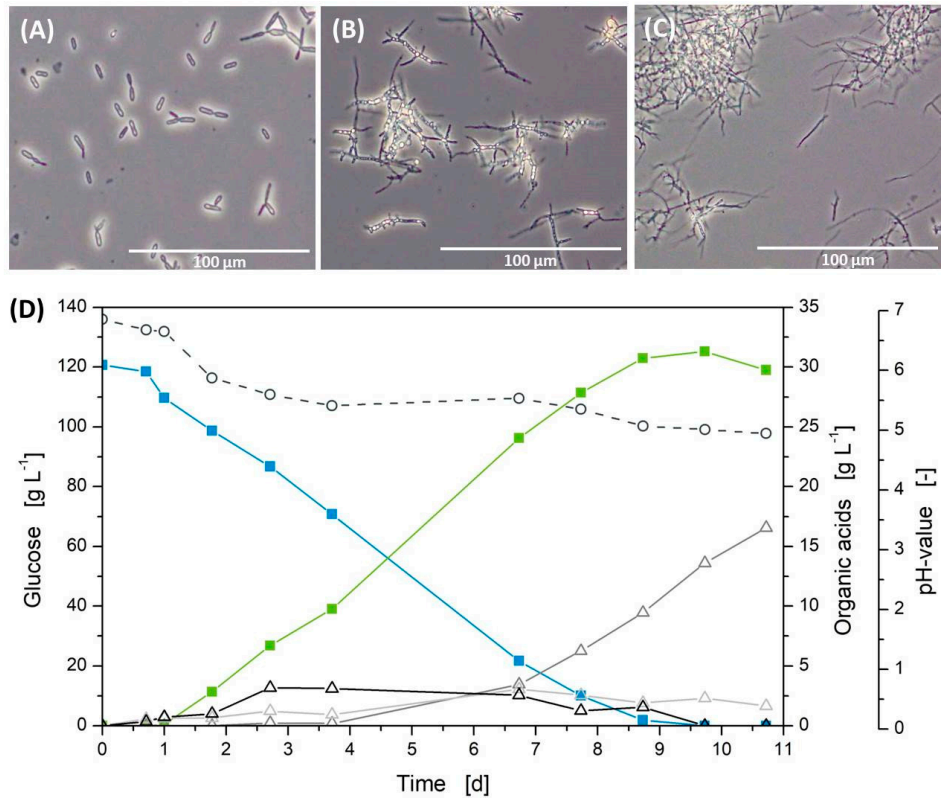

Figure 1. Cultivation of $U$. rabenhorstiana in $250 \mathrm{~mL}$ shake flasks in standard Tabuchi-medium (D) and its corresponding morphology (A): 0-2 days; (B): 2-7 days; (C): 7-11 days. Glucose (blue square), itaconic acid (green square), $\alpha$-ketoglutaric acid (grey triangle), succinic acid (black triangle), malic acid (light grey triangle), $\mathrm{pH}$ (black circle), $120 \mathrm{rpm}, 30{ }^{\circ} \mathrm{C}, 1 \%(v / v)$ inoculum.

\subsection{Influence of Media Components}

To determine the influence of media components, titer, yield, and productivity of a cultivation with $120 \mathrm{~g} \cdot \mathrm{L}^{-1}$ initial glucose, performed in shake flasks after 7.8 days, are shown in Figure 2 . In the case of the variating initial glucose concentrations (Figure 2A), the point in time of glucose limitation was analyzed. $50 \mathrm{~g} \cdot \mathrm{L}^{-1}$ glucose were consumed in 3.7 days, $100 \mathrm{~g} \cdot \mathrm{L}^{-1}$ in 6.7 days, $120 \mathrm{~g} \cdot \mathrm{L}^{-1} \mathrm{in}$ 8.7 days, and $150 \mathrm{~g} \cdot \mathrm{L}^{-1}$ in 10.7 days. Further, $200 \mathrm{~g} \cdot \mathrm{L}^{-1}$ glucose was not completely consumed by $U$. rabenhorstiana and $35 \mathrm{~g} \cdot \mathrm{L}^{-1}$, and remained while the concentration of itaconic acid was constant after 15 days. With increasing initial glucose concentration, the titer of itaconic acid increased, but the productivity and yield decreased slightly from $0.16 \mathrm{~g}(\mathrm{~L} \cdot \mathrm{h})^{-1}$ to $0.09 \mathrm{~g}(\mathrm{~L} \cdot \mathrm{h})^{-1}$ and from $0.27(w / w)$ to $0.20(w / w)$ for glucose concentrations larger than $100 \mathrm{~g} \cdot \mathrm{L}^{-1}$. The amount of $\alpha$-ketoglutaric, succinic, and malic acid of the total organic acid concentration was raised from $15.5 \%\left(50 \mathrm{~g} \cdot \mathrm{L}^{-1} \mathrm{glucose}\right)$ 
over $33.7 \%$ (120 g. $\mathrm{L}^{-1}$ glucose) to $50.1 \%\left(200 \mathrm{~g} \cdot \mathrm{L}^{-1}\right.$ glucose). In case of different ammonia chloride concentrations, the highest titer of $31.8 \mathrm{~g} \cdot \mathrm{L}^{-1}$ itaconic acid, a productivity of $0.17 \mathrm{~g}(\mathrm{~L} \cdot \mathrm{h})^{-1}$, and a yield of $0.26(w / w)$ was achieved using $1.6 \mathrm{~g} \cdot \mathrm{L}^{-1} \mathrm{NH}_{4} \mathrm{Cl}$, which corresponded to the used concentration in standard Tabuchi-medium (Figure 2B). With a lower concentration of $1 \mathrm{~g} \cdot \mathrm{L}^{-1} \mathrm{NH}_{4} \mathrm{Cl}$ and higher concentrations between 3 and $7 \mathrm{~g} \cdot \mathrm{L}^{-1} \mathrm{NH}_{4} \mathrm{Cl}$ the titer, productivity and yield decreased up to $35 \%$. Also, the chosen concentration of $0.2 \mathrm{~g} \cdot \mathrm{L}^{-1} \mathrm{MgSO}_{4} \cdot 7 \mathrm{H}_{2} \mathrm{O}$ in Tabuchi-medium was optimal for itaconic acid production with $U$. rabenhorstiana, and a titer of $28.9 \mathrm{~g} \cdot \mathrm{L}^{-1}$ with a productivity of $0.16 \mathrm{~g}(\mathrm{~L} \cdot \mathrm{h})^{-1}$ was reached (Figure 2C). Lower or higher levels of magnesium resulted in a decrease of all target values. In the concentration range of $0.1-1 \mathrm{~g} \cdot \mathrm{L}^{-1} \mathrm{KH}_{2} \mathrm{PO}_{4}$, there were no significant differences between the titer, yield, and productivity. All cultivations yielded in titers of $29.3 \mathrm{~g} \cdot \mathrm{L}^{-1} \pm 1.2 \mathrm{~g} \cdot \mathrm{L}^{-1}$ with a productivity between $0.15-0.16 \mathrm{~g}(\mathrm{~L} \cdot \mathrm{h})^{-1}$ and a yield of $0.24-0.25(w / w)$ (Figure 2D). In the range of $0.5-25 \mathrm{mg} \cdot \mathrm{L}^{-1} \mathrm{FeSO}_{4} \cdot 7 \mathrm{H}_{2} \mathrm{O}$, the itaconic acid decreased from $32.4 \mathrm{~g} \cdot \mathrm{L}^{-1}$ to $24.2 \mathrm{~g} \cdot \mathrm{L}^{-1}$ (Figure $2 \mathrm{E}$ ). The productivity of $0.17 \mathrm{~g}(\mathrm{~L} \cdot \mathrm{h})^{-1}$ was reduced by $17 \%$ and the yield of $0.3(w / w)$ itaconic acid by $25 \%$. With increasing yeast extract concentration $\left(0.25-1.5 \mathrm{~g} \cdot \mathrm{L}^{-1}\right)$ the titer increased to $27.2 \mathrm{~g} \cdot \mathrm{L}^{-1}$ with a productivity of $0.15 \mathrm{~g}(\mathrm{~L} \cdot \mathrm{h})^{-1}$ at a concentration of $1.5 \mathrm{~g} \cdot \mathrm{L}^{-1}$ yeast extract (Figure $2 \mathrm{~F}$ ). A further increase in the yeast extract concentration up to $2 \mathrm{~g} \cdot \mathrm{L}^{-1}$ resulted in a decreased titer of $24 \mathrm{~g} \cdot \mathrm{L}^{-1}$ and a lowered productivity of $0.13 \mathrm{~g}(\mathrm{~L} \cdot \mathrm{h})^{-1}$. None of the media components had an influence on the filamentous growth.

\subsection{Monosaccharide Utilization}

It is intended to produce itaconic acid based on renewable feedstocks, e.g., lignocellulosic biomass, biomass with a high starch content, or molasses. The usability of the monosaccharides based on those feedstocks (arabinose, fructose, galactose, glucose, mannose, rhamnose, and xylose) were investigated with $100 \mathrm{~g} \cdot \mathrm{L}^{-1}$ of each sugar in test tubes (Table 1). For the precultivation, sucrose was used. Filamentous growth occurred on glucose, fructose, mannose, and xylose. An accumulation of long hyphae, a buildup of pellets with a diameter of $50 \mu \mathrm{m}$ grew with arabinose as substrate. The yield and productivity were very different depending on the substrate. For the reference cultivation with glucose, the productivity was $0.16 \mathrm{~g}(\mathrm{~L} \cdot \mathrm{h})^{-1}$ with a yield of $0.24(w / w)$. The productivity of $0.09 \mathrm{~g}(\mathrm{~L} \cdot \mathrm{h})^{-1}$ of itaconic acid with mannose was $44 \%$ lower, while the yield was in the same range with $0.22(w / w)$. Using fructose, the same productivity compared to mannose was achieved, but with a lower yield of $0.17(w / w)$. U. rabenhorstiana was able to use both pentoses for itaconic acid production, whereby the productivity with arabinose with $0.04 \mathrm{~g}(\mathrm{~L} \cdot \mathrm{h})^{-1}$ was twice as high as with xylose. In the cultivation with glactose, only traces of itaconic acid were detected. The yeast was not able to produce itaconic acid or even grow with rhamnose as single substrate.

Table 1. Cultivation of $U$. rabenhorstiana in test tubes with different monosaccharides as substrate (four days, $30^{\circ} \mathrm{C}, 120 \mathrm{rpm}$, inclination angle of $30^{\circ}$, and $1 \%(v / v)$ inoculum).

\begin{tabular}{ccc}
\hline Monosaccharide & Productivity $\left[\mathbf{g}(\mathbf{L} \cdot \mathbf{h})^{-\mathbf{1}}\right]$ & $\mathbf{Y}_{\mathbf{P} / \mathbf{S}}[\boldsymbol{w} / w]$ \\
\hline Glucose & 0.16 & 0.24 \\
Mannose & 0.09 & 0.22 \\
Fructose & 0.09 & 0.17 \\
Arabinose & 0.04 & 0.06 \\
Xylose & 0.02 & 0.04 \\
Galactose & $<0.01$ & $<0.01$ \\
Rhamnose & - & - \\
\hline
\end{tabular}



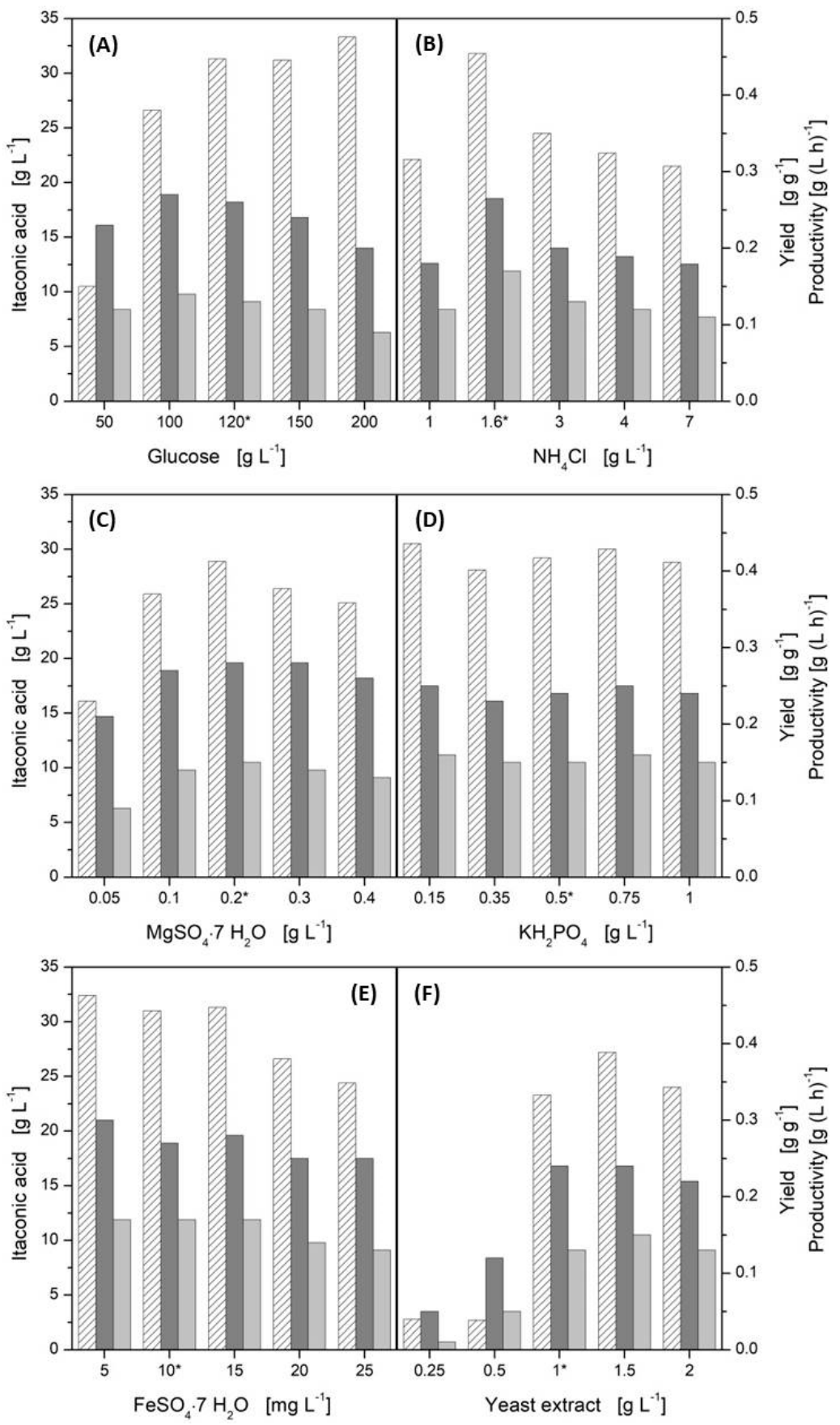

Figure 2. Influence of Tabuchi-medium components in $250 \mathrm{~mL}$ shake flasks on the final titer (dashed bar), yield (black bar), and productivity (grey bar) of $U$. rabenhorstiana at $120 \mathrm{rpm}$ and $30{ }^{\circ} \mathrm{C}$ after 7.8 days (B-F). Cultivation time for different initial glucose concentrations depended on the point of glucose limitation (A). Asterisks highlight the standard media composition.

\subsection{Influence of Sugar Degradation Products}

In case of lignocellulosic feedstocks, different sugar degradation products are formed due to the harsh conditions in the pretreatment. To test the inhibitory effect of sugar degradation products like weak acids or furan derivates, the components were added by the lowest expected concentration levels to the media. The effect of $0-2 \mathrm{~g} \cdot \mathrm{L}^{-1}$ acetic acid, formic acid, furfural, or hydroxymethylfurfural (HMF) was carried out in test tubes (Figure 3). A productivity of $0.15 \mathrm{~g}(\mathrm{~L} \cdot \mathrm{h})^{-1}$ with standard Tabuchi-medium without the addition of inhibitory components was reached. Up to a concentration of $0.5 \mathrm{~g} \cdot \mathrm{L}^{-1}$ formic 
acid, the productivity did not differ. The addition of $1 \mathrm{~g} \cdot \mathrm{L}^{-1}$ resulted in an increased productivity of approximately 1.4 times and decreased to $0.13 \mathrm{~g}(\mathrm{~L} \cdot \mathrm{h})^{-1}$ with $2 \mathrm{~g} \cdot \mathrm{L}^{-1}$ formic acid. The result was very similar with the addition of acetic acid. The standard productivity increased up to $0.19 \mathrm{~g}(\mathrm{~L} \cdot \mathrm{h})^{-1}$ by adding $0.5 \mathrm{~g} \cdot \mathrm{L}^{-1}$ acetic acid and was reduced to $0.13 \mathrm{~g}(\mathrm{~L} \cdot \mathrm{h})^{-1}$ by increasing the acetic acid concentration. Both furan derivates influenced the microorganism very strongly, amounts of $0.1 \mathrm{~g} \cdot \mathrm{L}^{-1}$ of $\mathrm{HMF}$ or $0.5 \mathrm{~g} \cdot \mathrm{L}^{-1}$ furfural already resulted in a growth inhibition. If the growth was not inhibited, the yeast grew filamentous and stored intracellular lipid droplets comparable with the cultivation without addition of inhibitors.

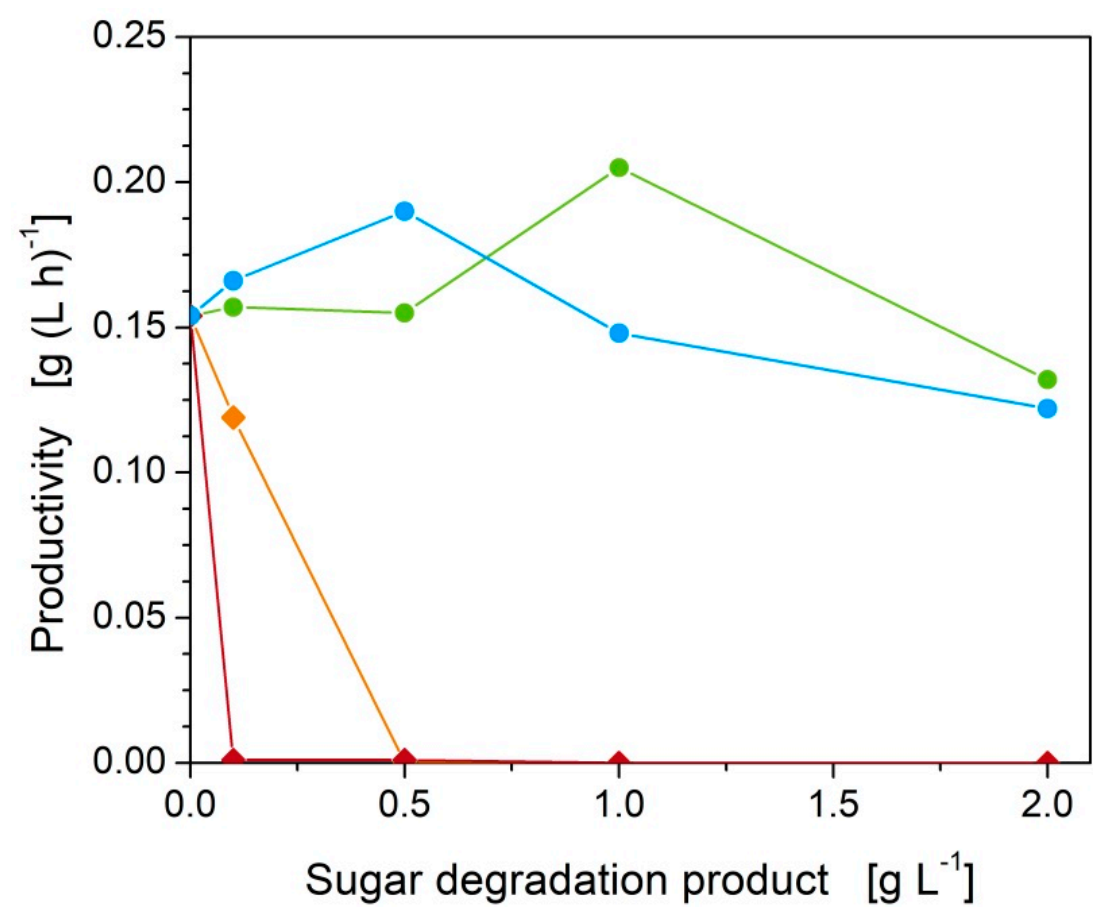

Figure 3. Inhibition effects of sugar degradation products on the itaconic acid productivity with U. rabenhorstiana in test tubes with Tabuchi-medium after four days, $30^{\circ} \mathrm{C}, 120 \mathrm{rpm}$, inclination angle of $30^{\circ}, \mathrm{pH}>5.5$, and $1 \%(v / v)$ inoculum. Acetic acid (blue circle), formic acid (green circle), HMF (red diamond), furfural (orange diamond).

\subsection{Influence of the $\mathrm{pH}$-Value in $1 \mathrm{~L}$-Bioreactor}

The $\mathrm{pH}$-value dropped in shake flask cultivations from $\mathrm{pH} 6.7$ to $\mathrm{pH} 4.9$ with $\mathrm{CaCO}_{3}$ as buffer. To estimate the influence of the $\mathrm{pH}$-value, the cultivation was transferred in $1 \mathrm{~L}$-bioreactors with $\mathrm{pH}$-control using $4 \mathrm{~m} \mathrm{NaOH}$ (Table 2). Moreover, the modified Tabuchi-medium with $100 \mathrm{~g} \cdot \mathrm{L}^{-1}$ glucose and $1.5 \mathrm{~g} \cdot \mathrm{L}^{-1}$ yeast extract was used, based on the findings regarding the tested media components. The highest titer of $31.7 \mathrm{~g} \cdot \mathrm{L}^{-1}$ itaconic acid with a productivity of $0.23 \mathrm{~g}(\mathrm{~L} \cdot \mathrm{h})^{-1}$ and a yield of $0.34 \mathrm{w}(\mathrm{w} / \mathrm{w})$ was reached with a controlled $\mathrm{pH}$ of 6.0. Beside itaconic acid, $0.4 \mathrm{~g} \cdot \mathrm{L}^{-1} \alpha$-ketoglutaric acid, $2 \mathrm{~g} \cdot \mathrm{L}^{-1}$ malic acid, $2.9 \mathrm{~g} \cdot \mathrm{L}^{-1}$ succinic acid, and the unknown product $\left(<1 \mathrm{~g} \cdot \mathrm{L}^{-1}\right)$ were produced. The rate of the byproducts did not differ among the tested $\mathrm{pH}$-values; also, the $\mathrm{pH}$-value did not have any influence on the filamentous growth of the yeast and formation of intracellular lipids. 
Table 2. Cultivation results of $U$. rabenhorstiana with $\mathrm{pH}$-control in modified Tabuchi-medium with $100 \mathrm{~g} \cdot \mathrm{L}^{-1}$ glucose and $1.5 \mathrm{~g} \cdot \mathrm{L}^{-1}$ yeast extract in $1 \mathrm{~L}$-bioreactor $\left(30^{\circ} \mathrm{C}, 500 \mathrm{rpm}, 0.1 \mathrm{vvm}, 4 \mathrm{~m} \mathrm{NaOH}\right)$.

\begin{tabular}{cccc}
\hline $\mathbf{p H}-$ Value $[-]$ & Itaconic Acid $\left[\mathbf{g} \cdot \mathbf{L}^{-\mathbf{1}}\right]$ & Productivity $\left[\mathbf{g}(\mathbf{L} \cdot \mathbf{h})^{-\mathbf{1}}\right]$ & $\mathbf{Y}_{\mathbf{P} / \mathbf{S}}[w / w]$ \\
\hline 5.5 & 23.7 & 0.15 & 0.25 \\
6.0 & 31.7 & 0.23 & 0.34 \\
6.5 & 18.6 & 0.12 & 0.19 \\
7.0 & 15.9 & 0.10 & 0.16 \\
\hline
\end{tabular}

\subsection{Influence of Aeration in 1 L-Bioreactor}

The effect of aeration was tested in 1 L-bioreactors by different aeration rates between $0.1-1 \mathrm{vvm}$, the stirring rate was kept constant, and the $\mathrm{pH}$-value was regulated to $\mathrm{pH} 6.0$ (Table 3). An increasing aeration rate from 0.1 to $1 \mathrm{vvm}$ resulted in a decreased yield and titer of $20 \%$, as well as in a $45 \%$ lower productivity. In contrast, the formed biomass increased from $15.7 \mathrm{~g} \cdot \mathrm{L}^{-1}$ at $0.1 \mathrm{vvm}$ to $21.3 \mathrm{~g} \cdot \mathrm{L}^{-1}$ at $1 \mathrm{vvm}$. There were no significant differences between the by-product concentrations depending on the aeration rate, which corresponds to the concentrations described in Section 3.5.

Table 3. Influence of aeration on the cultivation of $U$. rabenhorstiana in modified Tabuchi-medium with $100 \mathrm{~g} \cdot \mathrm{L}^{-1}$ glucose and $1.5 \mathrm{~g} \cdot \mathrm{L}^{-1}$ yeast extract in $1 \mathrm{~L}$-bioreactor $\left(30^{\circ} \mathrm{C}, 500 \mathrm{rpm}, \mathrm{pH} 6.0\right)$.

\begin{tabular}{ccccc}
\hline Aeration [vvm] & Itaconic Acid $\left[\mathbf{g} \cdot \mathbf{L}^{-\mathbf{1}}\right]$ & Productivity $\left[\mathbf{g} \cdot(\mathbf{L} \cdot \mathbf{h})^{-\mathbf{1}}\right]$ & $\begin{array}{c}\mathbf{Y}_{\mathbf{P} / \mathbf{S}} \\
{[\mathbf{w} / \mathbf{w}]}\end{array}$ & $\mathbf{C D W}\left[\mathbf{g} \cdot \mathbf{L}^{-\mathbf{1}}\right.$ ] \\
\hline 0.1 & 29.8 & 0.22 & 0.30 & 15.7 \\
0.5 & 26.1 & 0.16 & 0.26 & 17.5 \\
1.0 & 23.6 & 0.12 & 0.24 & 21.3 \\
\hline
\end{tabular}

\subsection{Fed-Batch Mode in 1 L-Bioreactor with Glucose}

Glucose concentrations larger than $150 \mathrm{~g} \cdot \mathrm{L}^{-1}$ resulted in a decreased yield and productivity in shake flasks (Figure 2A). For this reason, a fed batch with glucose was realized at a constant $\mathrm{pH}$ of $\mathrm{pH} 6.0$ in a $1 \mathrm{~L}$-bioreactor (Figure 4). An initial glucose concentration of $100 \mathrm{~g} \cdot \mathrm{L}^{-1}$ was chosen. After five days, $73 \mathrm{~g} \cdot \mathrm{L}^{-1}$ and after 10 days, $25 \mathrm{~g} \cdot \mathrm{L}^{-1}$ glucose were added into the cultivation broth, in which the average glucose consumption rate was $0.73 \mathrm{~g}(\mathrm{~L} \cdot \mathrm{h})^{-1}$ for the first batch $(0-5$ days $), 0.53 \mathrm{~g}(\mathrm{~L} \cdot \mathrm{h})^{-1}$ for the second batch (5-10 days), and 0.28 for the third batch (10-15 days). The yield amounted to 0.31 ( $w / w)$ in the first batch and was constant with $0.26(w / w)$ in the second and third batches. The DO decreased to $2 \%$ within the first day and varied between $2 \%-20 \%$ during the further cultivation. After one day, the itaconic acid production started and rose to a final titer of $50.3 \mathrm{~g} \cdot \mathrm{L}^{-1}$ within 15 days. Beside itaconic acid, $3.6 \mathrm{~g} \cdot \mathrm{L}^{-1}$ malic acid, $13.6 \mathrm{~g} \cdot \mathrm{L}^{-1}$ succinic acid, $2.5 \mathrm{~g} \cdot \mathrm{L}^{-1} \alpha$-ketoglutaric acid, and the unknown product $\left(<10 \mathrm{~g} \cdot \mathrm{L}^{-1}\right)$ were formed by $17.2 \mathrm{~g} \cdot \mathrm{L}^{-1}$ filamentous biomass (Appendix A, Figure A2). This cultivation resulted in a productivity of $0.14 \mathrm{~g}(\mathrm{~L} \cdot \mathrm{h})^{-1}$ with an overall yield of $0.27(w / w)$ after 15 days. Further, $175 \mathrm{~mL}$ of a $4 \mathrm{~m} \mathrm{NaOH}$ was used to keep the $\mathrm{pH}$-value constant at $\mathrm{pH}$ 6.0. After 15 days, the cell dry weight was analyzed regarding the fatty acids (Appendix A, Table A1); C16:0, C18:0, and C18:2 were the main elements. 


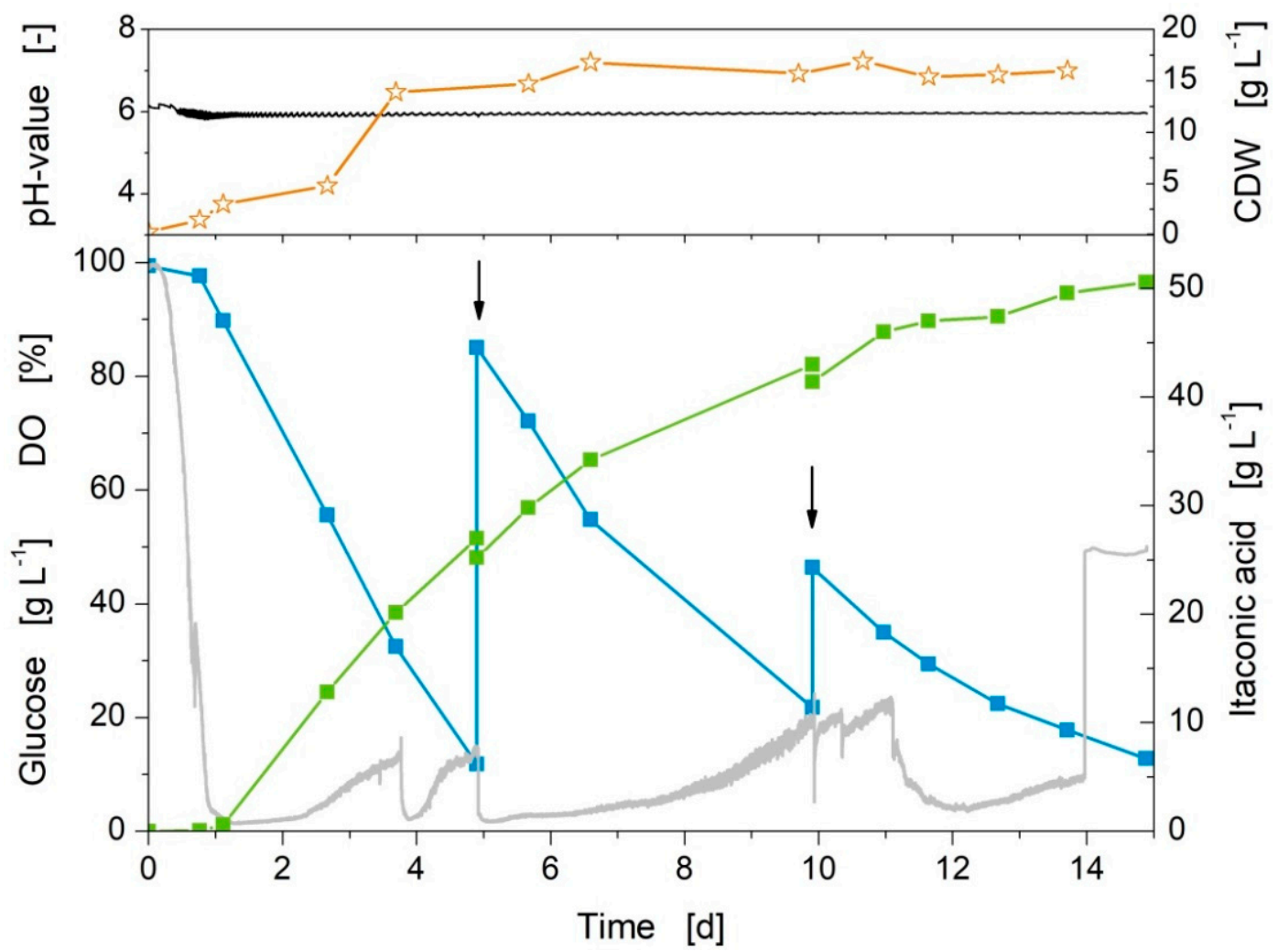

Figure 4. Fed batch with glucose in 1 L-bioreactor with modified Tabuchi-medium (initial glucose concentration $100 \mathrm{~g} \cdot \mathrm{L}^{-1}$ and $1.5 \mathrm{~g} \cdot \mathrm{L}^{-1}$ yeast extract) at $30^{\circ} \mathrm{C}, 500 \mathrm{rpm}, 0.1 \mathrm{vvm}, \mathrm{pH} 6.0$ with $4 \mathrm{~m} \mathrm{NaOH}$ as base and $1 \%(v / v)$ inoculum. Glucose (blue square), itaconic acid (green square), $\mathrm{pO}_{2}$ (grey line), $\mathrm{pH}$ (black line), cell dry weight (CDW) (orange asterisk), arrows symbolize the addition of glucose.

\section{Discussion}

In a standard cultivation in shake flasks, a final titer of $31.3 \mathrm{~g} \cdot \mathrm{L}^{-1}$ itaconic acid was achieved after 9.7 days without media and process optimization of $U$. rabenhorstiana. Additionally, succinic acid, malic acid, $\alpha$-ketoglutaric acid, an unknown product, and intracellular lipids were formed. Guevarra and Tabuchi reached a titer of about $16 \mathrm{~g} \cdot \mathrm{L}^{-1}$ itaconic acid in the same media after seven days and verified 2-hydroxyparaconic acid, itatartaric acid, and erythritol as byproducts with a total concentration of $30 \mathrm{~g} \cdot \mathrm{L}^{-1}$ [18]. Furthermore, they reduced the byproduct concentration to $19 \mathrm{~g} \cdot \mathrm{L}^{-1}$ with a constant itaconic acid titer by using an unbuffered media, whereby the final $\mathrm{pH}$-value was pH 2.8 [30]. Erythritol as the unknown byproduct could be excluded in this work. In comparison with the literature, the unknown product $\left(<1 \mathrm{~g} \cdot \mathrm{L}^{-1}\right)$ could either be 2-hydroxyparaconic acid or itatartaric acid (Appendix A, Figure A1) $[18,23,30]$ and must be characterized precisely in a further study. Moreover, the formation of different organic acids and intracellular lipid bodies by Ustilaginaceae besides itaconic acid production are very well known [5,19], as well as the production of cellobiose lipids and mannosylerythritol lipids [20,29], which were not proved in this study.

A point-by-point analysis of each media component indicated that the chosen concentrations of each component in the Tabuchi-medium were nearly optimal for itaconic acid production with $U$. rabenhorstiana. Only the glucose and yeast extract concentrations were adjusted from $120 \mathrm{~g} \cdot \mathrm{L}^{-1}$ to $100 \mathrm{~g} \cdot \mathrm{L}^{-1}$ for glucose and from $1 \mathrm{~g} \cdot \mathrm{L}^{-1}$ to $1.5 \mathrm{~g} \cdot \mathrm{L}^{-1}$ for yeast extract in the modified Tabuchi-medium. Increased glucose concentration resulted in an increased final titer, but the yield and productivity decreased with glucose concentrations $>100 \mathrm{~g} \cdot \mathrm{L}^{-1}$. The decreased yield and productivity can be explained by a higher osmotic stress and a higher number of byproducts. A very similar result was obtained by the production of itaconic acid with $U$. maydis [19]. This microorganism also showed lower yields at higher initial glucose concentrations, explained by the formation of other organic 
acids, polyols, and glycolipids. The increase of yeast extract by $0.5 \mathrm{~g} \cdot \mathrm{L}^{-1}$ raised the titer, productivity, and yield. A further increase of yeast extract did not result in an improved titer, suggesting that a limitation of vitamins, amino acids, salts, trace elements or nucleic acids [33] is prevented with a concentration $>1.5 \mathrm{~g} \cdot \mathrm{L}^{-1}$ yeast extract. The itaconic acid overproduction by $U$. maydis or $P$. antarctica are mainly triggered by an ammonium limitation, higher concentrations of $\mathrm{NH}_{4} \mathrm{Cl}>4 \mathrm{~g} \cdot \mathrm{L}^{-1}$ resulted in lower itaconic acid yields and an increase in biomass for $U$. maydis $[5,14,19]$. What is more, in this study, the ammonium concentration had the strongest influence on the fermentation performance of $U$. rabenhorstiana. A concentration of $1.6 \mathrm{~g} \cdot \mathrm{L}^{-1} \mathrm{NH}_{4} \mathrm{Cl}$ was optimal for itaconic acid production, and higher concentrations resulted in reduced yields and productivities as described already for $U$. maydis. For this reason, it can be assumed that an ammonium limitation caused the itaconic acid overproduction of $U$. rabenhorstiana. Further, the nitrogen limitation caused the accumulation of intracellular lipid droplets, which are mostly triacylglycerols [21,34]. A secretion of cellobiose lipids and mannosylerythritol lipids in the form of needle-like crystals or oily droplets of $U$. maydis [20], could not be verified for $U$. rabenhorstiana.

To use alternative, low-cost, or lignocellulosic feedstocks for itaconic acid production, it is important to use a microorganism, which is able to consume different monosaccharides and is robust towards varying impurities. In this study, it was worked out that $U$. rabenhorstiana is able to grow and produce itaconic acid from different monosaccharides like glucose, fructose, mannose, xylose, arabinose, and galactose. The highest productivity was reached with glucose, followed by fructose and mannose. Because the precultivation was based on sucrose, composed of glucose and fructose, it can be assumed that the cultivation with fructose was therefore such successful. An adaption to the used monosaccharide of the microorganisms in the preculture or a mixture of several monosaccharides with glucose would probably lead to higher productivity and yield using that single monosaccharide in the main culture. Furthermore, the plant pathogen $U$. rabenhorstiana is supposed to degrade a range of biomass-based polymers [35-37]. For industrial itaconic acid production, the filamentous fungus $A$. terreus is used, which is very sensitive to weak acids, furan derivates, metal ions, and other impurities, which are contained in such substrates $[11,12,38]$. U. maydis is described as a very robust microorganism $[5,22,39]$. U rabenhorstiana was also not influenced by the addition of weak acid concentrations up to $2 \mathrm{~g} \cdot \mathrm{L}^{-1}$ in the main culture. A major advantage of the cultivation of Ustilaginaceae is the $\mathrm{pH}$ range of 5.0-6.5, whereby the dissociated weak acids cannot cross the plasma membrane into the cytosol and affect the intracellular $\mathrm{pH}$-value [40,41]. A positive effect on the itaconic acid productivity was even achieved with the addition of $0.5 \mathrm{~g} \cdot \mathrm{L}^{-1}$ acetic acid or $1 \mathrm{~g} \cdot \mathrm{L}^{-1}$ formic acid. This positive influence of low weak acid concentrations in cultivation media is already known from itaconic acid production with $A$. terreus, ethanol production with $S$. cerevisiae, or enzyme production with T. reesei [12,42-44]. In contrast, low concentrations of $0.1 \mathrm{~g} \cdot \mathrm{L}^{-1} \mathrm{HMF}$ or $0.5 \mathrm{~g} \cdot \mathrm{L}^{-1}$ furfural are growth limiting factors; both furan derivates reduce the activity of a number of important intracellular enzymes of the maintenance metabolism, e.g., pyruvate dehydrogenase [45]. In particular, the activity of the pyruvate dehydrogenase is essential for cells, because this enzyme links glycolysis and citric acid cycle, which supplies the cell with energy intermediates. When using lignocellulosic biomass as feedstock for $U$. rabenhorstiana, it should be taken into account, that some robustness in relation to weak acids exists, but furan derivates influence the microorganisms mostly up to growth inhibition.

For further characterization of $U$. rabenhorstiana, the fermentation was transferred in $1 \mathrm{~L}$-bioreactors to investigate the influence of $\mathrm{pH}$-value and aeration. A constant $\mathrm{pH}$ of 6.0 and modified Tabuchi-medium yielded in the highest itaconic acid titer of $31.7 \mathrm{~g} \cdot \mathrm{L}^{-1}$, which is comparable with the titer in standard shake flask cultivation with Tabuchi-medium. However, the overall productivity was 1.7 times higher at a constant $\mathrm{pH}$-value than in shake flask experiments with $\mathrm{CaCO}_{3}$, whereby the $\mathrm{pH}$-value continuously decreased to $\mathrm{pH}$ 4.9. Moreover, the total concentration of by-products decreased by $66 \%$, which resulted in an increased itaconic acid yield. These suggested that the buffer capacity in shake flasks is insufficient. Buffer systems like $\mathrm{CaCO}_{3}$ or MES and its buffer capacity have a significant impact on the organic acid production of Ustilaginaceae not only on titer, but also on the ratio of 
products $[16,24,30]$. The higher the buffer capacity, the better is the itaconic acid titer in small-scale experiments, but $U$. maydis achieved the highest itaconic acid titer of $45.5-63.2 \mathrm{~g} \cdot \mathrm{L}^{-1}$ in cultivations with a constant $\mathrm{pH}$ of $6.0-6.5$ in bioreactors $[19,23]$. Consequently, $U$. maydis and $U$. rabenhorstiana have nearly the same requirements in $\mathrm{pH}$ and productivity. Titer and yield are positively influenced by a constant $\mathrm{pH}$-value.

In the literature, no detailed studies regarding influence of oxygen levels on the organic acid production with Ustilaginaceae exist. Only cultivation parameters like high shaking frequencies or stirrer speeds led to the conclusion that a high input of oxygen is necessary [10]. Contrary results were achieved for itaconic acid production with $U$. rabenhorstiana; the lowest aeration rate of $0.1 \mathrm{vvm}$ and a constant stirring rate of $500 \mathrm{rpm}$ yielded the best result regarding titer, productivity, and yield. Presumably, the increase in these values is related to the formation of $36 \%$ more biomass at higher aeration rates, because of a better supply of oxygen. In batch experiments, a maximum itaconic acid concentration of $33.3 \mathrm{~g} \cdot \mathrm{L}^{-1}$ with an initial glucose concentration of $200 \mathrm{~g} \cdot \mathrm{L}^{-1}$ was achieved, proving that initial glucose concentration $\geq 100 \mathrm{~g} \cdot \mathrm{L}^{-1}$ and a constant $\mathrm{pH}$-value of $\mathrm{pH} 6.0$ have a significant impact on the itaconic acid production with $U$. rabenhorstiana. Therefore, a cultivation in fed-batch mode with glucose was realized at $\mathrm{pH} 6.0$ and resulted in $50.3 \mathrm{~g} \cdot \mathrm{L}^{-1}$ itaconic acid. Comparing the batch cultivation with $200 \mathrm{~g} \cdot \mathrm{L}^{-1}$ glucose with the fed-batch cultivation in a bioreactor, the productivity and yield were 1.4 times and the final titer 1.5 times higher. Also, the formation of organic acid as byproducts was reduced. The number of byproducts of the overall organic acid concentration decreased from $50 \%$ in batch cultivation to $28 \%$ in fed-batch mode. Thereby, the amount of organic acids shifted from $\alpha$-ketoglutaric acid as the main byproduct in batch mode to succinic acid in fed-batch mode, due to the $\mathrm{pH}$-value of each cultivation [16]. The final titer and yield of this study are slightly increased compared to a wildtype strain of $U$. maydis, which reached $44.5 \mathrm{~g} \cdot \mathrm{L}^{-1}$ [19]. A higher final titer up to $63.2 \mathrm{~g} \cdot \mathrm{L}^{-1}$ or yield of $0.48(w / w)$ was only obtained by a genetical modification of $U$. maydis [23]. All in all, the fermentation broth was diluted by addition of $175 \mathrm{~mL} \mathrm{NaOH}$ as base. Considering the dilution, the wildtype of $U$. rabenhorstiana demonstrates the potential to produce up to $68 \mathrm{~g} \cdot \mathrm{L}^{-1}$ itaconic acid. However, in all main cultures, the unicellular growth of $U$. rabenhorstiana shifted to filamentous cells with depots of intracellular lipids. Neither the variation of media components nor the investigation of process parameters influenced the filamentous growth. The typical unicellular yeast-like growth of $U$. maydis for itaconic acid could not be achieved for $U$. rabenhorstiana in this study. This morphology would be a great advantage compared to the filamentous $A$. terreus regarding oxygen supply or viscosity, especially in large-scale fermentations [5,22], but was not focused in this study. In general, it is possible to generate a stable unicellular growth by deleting several genes [24]. The filamentous growth involved the accumulation of intracellular lipid droplets, which is initiated by nitrogen limitation, which in turn is needed for itaconic acid overproduction $[5,19,34]$. Furthermore, $89 \%$ of all fatty acids in U. rabenhorstiana were long-chain fatty acids C16:0, C18:0, and C18:2 and suggested the accumulation of triacylglycerols in the cells. The lipid bodies in $U$. maydis mainly contain triacylglycerols consisting of palmitic, linoleic, and oleic acids [21].

\section{Conclusions}

This study describes a known, but so far unspecified, itaconic acid producer-U. rabenhorstiana. The cultivation in shake flasks with a maximal final titer of $33.3 \mathrm{~g} \cdot \mathrm{L}^{-1}$ itaconic acid was transferred in a bioreactor. With a controlled $\mathrm{pH}$-value, a low initial glucose concentration, and fed-batch mode, a final titer of $50.3 \mathrm{~g} \cdot \mathrm{L}^{-1}$ was achieved, which is comparable with titer of other wildtype strains of Ustilago described in literature. However, the productivity and yield are rather low compared to $U$. maydis, which was studied very precisely in the last years regarding cultivation and process parameters as well as metabolic engineering strategies for further improvements in itaconic acid production. Transferring this knowledge from $U$. maydis to $U$. rabenhorstiana could result in a further increased final titer and improved yield and productivity. Particular attention should be paid to the morphology of the yeast and minimization of byproducts, mainly the formation of intracellular lipid droplets. Moreover, 
the wildtype strain $U$. rabenhorstiana turned out to be a robust and promising alternative itaconic acid producer based on renewable resources. All in all, this study serves a basis for further promising research regarding lignocellulosic hydrolysates.

Author Contributions: S.K. and M.L. designed and performed the experiments. U.P. and A.K. supervised the experiments. S.K. wrote the manuscript. All authors have read and agreed to the published version of the manuscript.

Funding: This work was carried out in the framework of the European Research Area Network for Industrial Biotechnology (ERA-IB project "Production of Organic Acids for Polyester Synthesis (POAP)") and was funded by the German Federal Ministry of Food and Agriculture, following a decision of the German Bundestag, via the Agency of Renewable Resources (Grant No. 22029312).

Conflicts of Interest: The authors declare no conflict of interest. The funder had no role in the design of the study; in the collection, analyses, or interpretation of data; in the writing of the manuscript, or in the decision to publish the results.

\section{Appendix A}

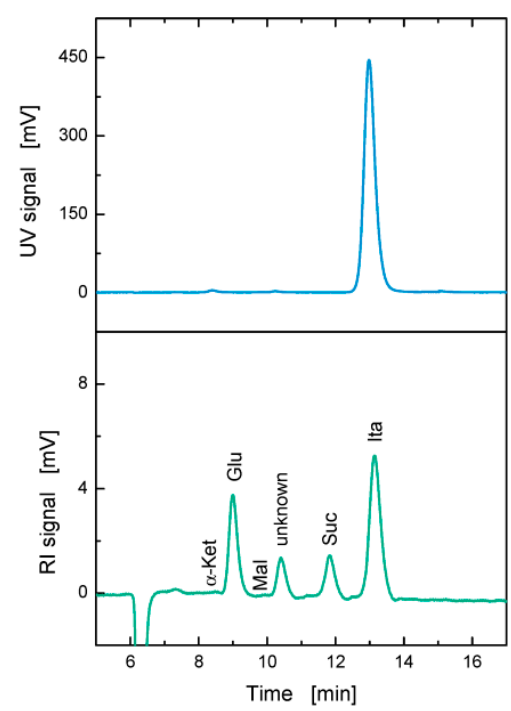

Figure A1. Representative HPLC analysis of a final sample (15 days) of a fed-batch cultivation in 1 L-bioreactor (Section 3.7). $\alpha$-ketoglutaric acid ( $\alpha$-Ket), glucose (Glu), malic acid (Mal), unknown product, succinic acid (Suc), itaconic acid (Ita).
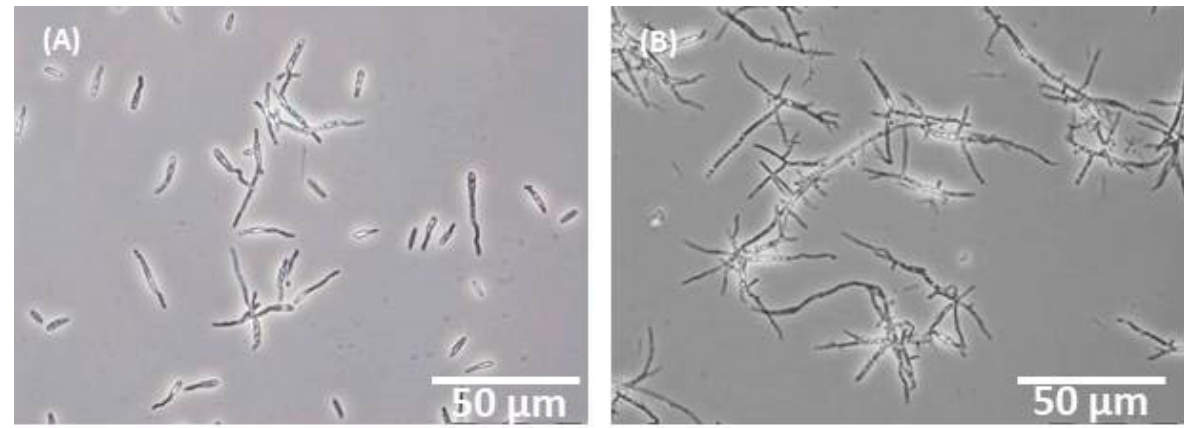

Figure A2. Corresponding morphology of $U$. rabenhorstiana in a fed-batch cultivation in 1 L-bioreactor (Section 3.7) after 1.1 days (A) and 6.6 days (B). 
Table A1. Analysis of fatty acids in intracellular lipid droplets in U. rabenhorstiana of a fed-batch cultivation in 1 L-bioreactor (Section 3.7).

\begin{tabular}{cc}
\hline Fatty Acid & Concentration $\left[\mathbf{m g} \cdot \mathbf{g}^{-\mathbf{1}} \mathbf{C D W}\right]$ \\
\hline $\mathrm{C} 14: 0$ & 1.46 \\
$\mathrm{C} 16: 0$ & 30.04 \\
$\mathrm{C} 16: 1$ & 1.55 \\
$\mathrm{C} 18: 0$ & 16.94 \\
$\mathrm{C} 18: 1$ & 1.83 \\
$\mathrm{C} 18: 2$ & 48.38 \\
$\mathrm{C} 22: 0$ & 4.42 \\
$\mathrm{C} 24: 0$ & 2.45 \\
\hline
\end{tabular}

\section{References}

1. Werpy, T.; Petersen, G. Top Value Added Chemicals from Biomass: Volume I-Results of Screening for Potential Candidates from Sugars and Synthesis Gas; National Renewable Energy Lab.: Golden, CO, USA, 2004.

2. Magalhaes, A.I.; de Carvalho, J.C.; Medina, J.D.C.; Soccol, C.R. Downstream process development in biotechnological itaconic acid manufacturing. Appl. Microbiol. Biotechnol. 2017, 101, 1-12. [CrossRef]

3. Robert, T.; Friebel, S. Itaconic acid-A versatile building block for renewable polyesters with enhanced functionality. Green Chem. 2016, 18, 2922-2934. [CrossRef]

4. Okabe, M.; Lies, D.; Kanamasa, S.; Park, E.Y. Biotechnological production of itaconic acid and its biosynthesis in Aspergillus terreus. Appl. Microbiol. Biotechnol. 2009, 84, 597-606. [CrossRef]

5. Klement, T.; Milker, S.; Jäger, G.; Grande, P.M.; de Maria, P.D.; Büchs, J. Biomass pretreatment affects Ustilago maydis in producing itaconic acid. Microb. Cell Factories 2012, 11, 43. [CrossRef]

6. Willke, T.; Vorlop, K.D. Biotechnological production of itaconic acid. Appl. Microbiol. Biotechnol. 2001, 56, 289-295. [CrossRef]

7. Hevekerl, A.; Kuenz, A.; Vorlop, K.D. Influence of the $\mathrm{pH}$ on the itaconic acid production with Aspergillus terreus. Appl. Microbiol. Biotechnol. 2014, 98, 10005-10012. [CrossRef]

8. Karaffa, L.; Diaz, R.; Papp, B.; Fekete, E.; Sandor, E.; Kubicek, C.P. A deficiency of manganese ions in the presence of high sugar concentrations is the critical parameter for achieving high yields of itaconic acid by Aspergillus terreus. Appl. Microbiol. Biotechnol. 2015, 99, 7937-7944. [CrossRef]

9. Krull, S.; Hevekerl, A.; Kuenz, A.; Prüße, U. Process development of itaconic acid production by a natural wild type strain of Aspergillus terreus to reach industrially relevant final titers. Appl. Microbiol. Biotechnol. 2017, 101, 4063-4072. [CrossRef]

10. Kuenz, A.; Krull, S. Biotechnological production of itaconic acid-things you have to know. Appl. Microbiol. Biotechnol. 2018, 102, 3901-3914. [CrossRef]

11. Kobayashi, T. Production of itaconic acid from wood waste. Process Biochem. 1978, 13, 15-22.

12. Krull, S.; Eidt, L.; Hevekerl, A.; Kuenz, A.; Prüße, U. Itaconic acid production from wheat chaff by Aspergillus terreus. Process Biochem. 2017, 63, 169-176. [CrossRef]

13. Wu, X.F.; Liu, Q.; Deng, Y.D.; Li, J.H.; Chen, X.J.; Gu, Y.Z.; Lv, X.J.; Zheng, Z.; Jiang, S.T.; Li, X.J. Production of itaconic acid by biotransformation of wheat bran hydrolysate with Aspergillus terreus CICC40205 mutant. Bioresour. Technol. 2017, 241, 25-34. [CrossRef]

14. Levinson, W.E.; Kurtzman, C.P.; Kuo, T.M. Production of itaconic acid by Pseudozyma antarctica NRRL Y-7808 under nitrogen-limited growth conditions. Enzym. Microb. Technol. 2006, 39, 824-827. [CrossRef]

15. Specht, R.; Andreas, A.; Kreyß, E.; Barth, G.; Bodinus, C. Verfahren zur Biotechnologischen Herstellung von Itaconsäure. DE Patent 102008011854 B4, 20 February 2014.

16. Geiser, E.; Wiebach, V.; Wierckx, N.; Blank, L.M. Prospecting the biodiversity of the fungal family Ustilaginaceae for the production of value-added chemicals. Fungal Biol. Biotechnol. 2014, 1, 2. [CrossRef]

17. Tabuchi, T.; Sugisawa, T.; Ishidori, T.; Nakahara, T.; Sugiyama, J. Itaconic Acid Fermentation by a Yeast Belonging to the Genus Candida. Agric. Biol. Chem. 1981, 45, 475-479. [CrossRef]

18. Guevarra, E.D.; Tabuchi, T. Accumulation of itaconic, 2-hydroxyparaconic, itatartaric, and malic-acids by strains of the genus Ustilago. Agric. Biol. Chem. 1990, 54, 2353-2358. [CrossRef] 
19. Maassen, N.; Panakova, M.; Wierckx, N.; Geiser, E.; Zimmermann, M.; Bolker, M.; Klinner, U.; Blank, L.M. Influence of carbon and nitrogen concentration on itaconic acid production by the smut fungus Ustilago maydis. Eng. Life Sci. 2014, 14, 129-134. [CrossRef]

20. Spoeckner, S.; Wray, V.; Nimtz, M.; Lang, S. Glycolipids of the smut fungus Ustilago maydis from cultivation on renewable resources. Appl. Microbiol. Biotechnol. 1999, 51, 33-39. [CrossRef]

21. Aguilar, L.R.; Pardo, J.P.; Lomeli, M.M.; Bocardo, O.I.L.; Oropeza, M.A.J.; Sanchez, G.G. Lipid droplets accumulation and other biochemical changes induced in the fungal pathogen Ustilago maydis under nitrogen-starvation. Arch. Microbiol. 2017, 199, 1195-1209. [CrossRef]

22. Regestein, L.; Klement, T.; Grande, P.; Kreyenschulte, D.; Heyman, B.; Maßmann, T.; Eggert, A.; Sengpiel, R.; Wang, Y.; Wierckx, N. From beech wood to itaconic acid: Case study on biorefinery process integration. Biotechnol. Biofuels 2018, 11, 1-11. [CrossRef]

23. Geiser, E.; Przybilla, S.K.; Engel, M.; Kleineberg, W.; Büttner, L.; Sarikaya, E.; Den Hartog, T.; Klankermayer, J.; Leitner, W.; Bölker, M. Genetic and biochemical insights into the itaconate pathway of Ustilago maydis enable enhanced production. Metab. Eng. 2016, 38, 427-435. [CrossRef]

24. Tehrani, H.H.; Tharmasothirajan, A.; Track, E.; Blank, L.M.; Wierckx, N. Engineering the morphology and metabolism of $\mathrm{pH}$ tolerant Ustilago cynodontis for efficient itaconic acid production. Metab. Eng. 2019, 54, 293-300. [CrossRef]

25. Geiser, E.; Przybilla, S.K.; Friedrich, A.; Buckel, W.; Wierckx, N.; Blank, L.M.; Bolker, M. Ustilago maydis produces itaconic acid via the unusual intermediate trans-aconitate. Microb. Biotechnol. 2016, 9, 116-126. [CrossRef]

26. Zambanini, T.; Hartmann, S.K.; Schmitz, L.M.; Buttner, L.; Hosseinpour Tehrani, H.; Geiser, E.; Beudels, M.; Venc, D.; Wandrey, G.; Buchs, J.; et al. Promoters from the itaconate cluster of Ustilago maydis are induced by nitrogen depletion. Fungal Biol. Biotechnol. 2017, 4, 11. [CrossRef]

27. Wierckx, N.; Agrimi, G.; Lubeck, P.S.; Steiger, M.G.; Mira, N.P.; Punt, P.J. Metabolic specialization in itaconic acid production: A tale of two fungi. Curr. Opin. Biotechnol. 2019, 62, 153-159. [CrossRef]

28. Zambanini, T.; Hosseinpour Tehrani, H.; Geiser, E.; Merker, D.; Schleese, S.; Krabbe, J.; Buescher, J.M.; Meurer, G.; Wierckx, N.; Blank, L.M. Efficient itaconic acid production from glycerol with Ustilago vetiveriae TZ1. Biotechnol. Biofuels 2017, 10, 131. [CrossRef]

29. Haskins, R.; Thorn, J.; Boothroyd, B. Biochemistry of the Ustilaginales: XI. Metabolic products of Ustilago zeae in submerged culture. Can. J. Microbiol. 1955, 1, 749-756. [CrossRef]

30. Guevarra, E.D.; Tabuchi, T. Production of 2-hydroxyparaconic and itatartaric acids by Ustilago cynodontis and simple recovery process of the acids. Agric. Biol. Chem. 1990, 54, 2359-2365. [CrossRef]

31. Lewis, T.; Nichols, P.D.; McMeekin, T.A. Evaluation of extraction methods for recovery of fatty acids from lipid-producing microheterotrophs. J. Microbiol. Methods 2000, 43, 107-116. [CrossRef]

32. Klose, J.; Kronstad, J.W. The multifunctional beta-oxidation enzyme is required for full symptom development by the biotrophic maize pathogen Ustilago maydis. Eukaryot. Cell 2006, 5, 2047-2061. [CrossRef]

33. Sommer, R. Yeast extracts: Production, properties and components. Food Aust. 1998, 50, 181-183.

34. Zavala-Moreno, A.; Arreguin-Espinosa, R.; Pardo, J.P.; Romero-Aguilar, L.; Guerra-Sánchez, G. Nitrogen source affects glycolipid production and lipid accumulation in the phytopathogen fungus Ustilago maydis. Adv. Microbiol. 2014, 4, 934. [CrossRef]

35. Gibson, D.M.; King, B.C.; Hayes, M.L.; Bergstrom, G.C. Plant pathogens as a source of diverse enzymes for lignocellulose digestion. Curr. Opin. Microbiol. 2011, 14, 264-270. [CrossRef]

36. Geiser, E.; Reindl, M.; Blank, L.M.; Feldbrügge, M.; Wierckx, N.; Schipper, K. Activating intrinsic carbohydrate-active enzymes of the smut fungus Ustilago maydis for the degradation of plant cell wall components. Appl. Environ. Microbiol. 2016, 82, 5174-5185. [CrossRef]

37. Couturier, M.; Navarro, D.; Olivé, C.; Chevret, D.; Haon, M.; Favel, A.; Lesage-Meessen, L.; Henrissat, B.; Coutinho, P.M.; Berrin, J.-G. Post-genomic analyses of fungal lignocellulosic biomass degradation reveal the unexpected potential of the plant pathogen Ustilago maydis. BMC Genom. 2012, 13, 57. [CrossRef]

38. Gyamerah, M. Factors affecting the growth form of Aspergillus terreus NRRL 1960 in relation to itaconic acid fermentation. Appl. Microbiol. Biotechnol. 1995, 44, 356-361. [CrossRef]

39. Benito, B.; Garciadeblás, B.; Pérez-Martín, J.; Rodríguez-Navarro, A. Growth at high pH and sodium and potassium tolerance in media above the cytoplasmic $\mathrm{pH}$ depend on ENA ATPases in Ustilago maydis. Eukaryot. Cell 2009, 8, 821-829. [CrossRef] 
40. Stratford, M.; Nebe-von-Caron, G.; Steels, H.; Novodvorska, M.; Ueckert, J.; Archer, D.B. Weak-acid preservatives: $\mathrm{pH}$ and proton movements in the yeast Saccharomyces cerevisiae. Int. J. Food Microbiol. 2013, 161, 164-171. [CrossRef]

41. Lambert, R.; Stratford, M. Weak-acid preservatives: Modelling microbial inhibition and response. J. Appl. Microbiol. 1999, 86, 157-164. [CrossRef]

42. Larsson, S.; Palmqvist, E.; Hahn-Hägerdal, B.; Tengborg, C.; Stenberg, K.; Zacchi, G.; Nilvebrant, N.-O. The generation of fermentation inhibitors during dilute acid hydrolysis of softwood. Enzym. Microb. Technol. 1999, 24, 151-159. [CrossRef]

43. Maiorella, B.; Blanch, H.W.; Wilke, C.R. By-product inhibition effects on ethanolic fermentation by Saccharomyces cerevisiae. Biotechnol. Bioeng. 1983, 25, 103-121. [CrossRef]

44. Szengyel, Z.; Zacchi, G. Effect of acetic acid and furfural on cellulase production of Trichoderma reesei RUT C30. Appl. Biochem. Biotechnol. 2000, 89, 31-42. [CrossRef]

45. Modig, T.; Liden, G.; Taherzadeh, M.J. Inhibition effects of furfural on alcohol dehydrogenase, aldehyde dehydrogenase and pyruvate dehydrogenase. Biochem. J. 2002, 363, 769-776. [CrossRef]

(C) 2020 by the authors. Licensee MDPI, Basel, Switzerland. This article is an open access article distributed under the terms and conditions of the Creative Commons Attribution (CC BY) license (http://creativecommons.org/licenses/by/4.0/). 